\title{
A STUDY OF DIGITAL BANKING FACILITIES WITH REFERENCE TO KUSHALNAGAR TOWN PANCHAYATH DISTRICT OF COORG
}

\author{
M.N. Prakasha \\ Research Scholar, ISBR Business School, India
}

\begin{abstract}
Banking industry in India is facing unprecedented competition from non traditional banking institutions, which now offer banking and financial services over the internet. The deregulation of the banking industry coupled with the emergence of new technologies, are enabling new competitor to enter the financial services market quickly. Digital banking or E-Banking is an umbrella term for the process by which electronically without visiting a bank. User with a personal computer can get connected to his banks website to perform any o the virtual banking functions. In internet banking system the bank has a centralized database that is AHADweb-enabled. All the services that the bank has permitted on the internet are displayed in menu. Any service can be selected and further interaction is dictated by the nature of services.
\end{abstract}

Keywords: Micro, Small and Medium Enterprises, Gross Domestic Product, Employment generation, Poverty, Growth and Development.

Cite this Article: M.N. Prakasha, A Study of Digital Banking Facilities with Reference to Kushalnagar Town Panchayath District of Coorg, Journal of Management (JOM), 6 (6), 2019, pp. 1-8.

http://www.iaeme.com/JOM/issues.asp?JType=JOM\&VType=6\&IType $=6$

\section{INTRODUCTION}

Banking industry in India is facing unprecedented competition from non - traditional banking institutions, which now offer banking and financial services over the internet. The deregulation of the banking industry coupled with the emergence of new technologies, are enabling new competitor to enter the financial services market quickly. Digital banking or E-Banking is an umbrella term for the process by which electronically without visiting a bank. User with a personal computer can get connected to his banks website to perform any o the virtual banking functions. In internet banking system the bank has a centralized database that is AHADwebenabled. All the services that the bank has permitted on the internet are displayed in menu. Any service can be selected and further interaction is dictated by the nature of services.

E- Banking is a generic term for delivery of banking services and products through electronic channels, such as the telephone the internet, the cell phone, etc., 
A Study of Digital Banking Facilities: With Reference to kushalnagar in Coorg District of Karnataka

\section{ELECTRONIC PAYMENT MODE}

The payment system plays a total role in business dealings. E - Payment system paves way to the consumers for buying products through internet mode. So the advertisements are made through web pages. The consumers can buy the product and they can make the payment by any one of the following methods.

$\mathrm{E}$ - Cheques: $\mathrm{E}$ - Cheques are mostly used in business to business in $\mathrm{E}$ - Commerce. Those E- Cheques carry a sign in digital form. The cheques are exchanged between financial institutions.

E - CREDIT CARDS: E - Credit Card enhances the payment through online mode, various security methods are adopted for avoiding major risks while paying through electronic method. But the time and cost of processing will be increased on the tightening process of security.

E - Cash: E - Cash is an electronic form of currency payment. The exchange of money to ecash is mode by using internet or another e - cash retailer.

Smart Cards: Smart cards are distributed by banks. A Customer holding a smart card would not need to carry cash. It will perform all the functions of debit card, ATM card, etc., and holder will be able to do things like making telephone calls.

E - Banking Services: Now E - banking offers various services to its customers. Account Information: The user can get information of the operative accounts, deposit accounts, loan accounts, and all accounts along with the following information.

Last no. of transactions. Statement of cheque status of cheques issued.

Lien details.

Flexi deposit details.

Tax deduction at source details.

Transfer of Funds: Under this option the user gets the facility to transfer funds between different accounts. The options available to him are as transfer of funds between self-accounts and from self-accounts to third party account within the core banking branches of bank.

Scheduled transfer for a future date, Status of fund transfer.

Mails: Every user of union e - banking retail service is linked to a relationship manager who looks into the mails and request made by the user. For this the user is provided with a mail option, which they can use for communicating with the relationship manager. The mail option enables him to compose and send mails to his RM, receive mails from the RM, Create different folders for storing mails, mail alert box for receiving alert mails from bank and Storing of sent items.

\section{STATEMENT OF THE PROBLEM}

Banking is a customer oriented service industry, where the customer is in focus and customer service is a differentiating factor. The traditional functions of banking are very limited one. Economic reforms initiated by the government of India in the early $1990^{\text {ee }}$ s have brought about a sea change in the operational environment of the financial sector and the functioning outlook of Indian banks. Customer expects many services with the various deliver mode in the speedy and economically. Modern World Bank is fully based on computerization connected with the Internet. Digital Banking which also treated as E Banking or Internet banking provides new opportunities for banks to expand their markets and services not only in the local level but also into the world level. The Digital banking revolution has made it possible to provide ease and 
flexibility in banking operations to the benefit of customers. The Digital banking or e- banking has made the customer say goodbye to limited time banking and local area operation. Due to the enormous benefits of Internet banking most of the customer opt for Digital Banking services.

This study provides an opportunity to know role of digital banking service in banks and their facilities in Kushalnagar of Coorg. The present study also focuses on the awareness of the technology oriented services offered to their customers at kushalnagar fo coorg..

\section{OBJECTIVES OF THE STUDY}

To study and analyses the factors that are motivating the bankers to facilitate the customers of Kushalnagar of coorg district.

To study and analyze the satisfaction of customers of. Kushalnagar of coorg district

\section{REVIEW OF LITERATURE}

Dr C. Paramasivan (2009) in his studies entitled "Customer satisfaction through information technology in commercial bankse highlighted that, customers are satisfied with banking services to some extent and the bankers should try to improve their services at an affordable cost with the help of information technology.

Mishra (2005) in his paper explained the advantages and the security concerns about internet banking. According to him, improved customer access, offering of more services, increased customer loyalty, attracting new customers are the primary drivers of internet banking. But in a survey conducted by the online banking association, member institutions rated security as the most important concern of online banking.

sNyangosiet al. (2009) collected customers' opinions regarding the importance of e-Banking and the adoption levels of different e-Banking technologies in India and Kenya. The study highlighted the trends of e-banking indicators in both countries. The overall result indicates that customers in both countries have developed a positive attitude and they give much importance to the emergence of e-banking.

\section{RESEARCH METHODOLOGY}

Primary data will be collected afresh and for the first time. It is the data originates by the researcher specifically to address the research problem. In this study, primary data will be collected primarily through discussions with officials and customers of various banks to understand the various digital banking facilities provided by their bankers of Kushalnagar of coorg district. Secondary data includes those data which will be collected from internet, the brochures, Advertisements, magazines and the printed material available from the public and private sector banks of Kushalnagar of coorg district.

\subsection{Sampling Design}

The Present Paper studies the Banking facilities or services offered atKushalnagarof coorg district. Kushalnagar is a city and a city panchayat In coorg district in state of Karnataka. It is also the headquarter of somwerpet. The city has a population of about 957,352 as per 2011 census. This coastal city is witnessing rapid growth.

To facilitate the entrepreneur and other people 18 commercial banks are available with the Internet Banking Services. The numbers of Internet bank users are invariably high. So the researcher has adopted convenient sampling method and selects the 100 respondents from the all banks. 


\subsection{Analysis and Interpretation}

Nature of Account Nowadays banks offered various types of account for different types of customer. Data regarding the type of banks account of respondents is collected and depicted in Table 1.1.

Table 1.1 Type of Account

\begin{tabular}{|c|l|c|c|}
\hline S. No & \multicolumn{1}{|c|}{ Kind of Account } & Number of Respondents & Percentage \\
\hline 1 & Savings Account & 21 & 21 \\
\hline 2 & Current Account & 50 & 50 \\
\hline 3 & Salary Account & 16 & 16 \\
\hline 4 & Cash Credit Account & 13 & 13 \\
\hline & Total & 100 & 100 \\
\hline
\end{tabular}

Source: Primary Data

It is clear from the Table 1.1 that out of 100,21 per cent respondents have savings bank account, 50 per cent have current account, 16 per cent of the respondents have salary accounts, and remaining 10 per cent of the respondents have time deposit account.

\subsection{Information Sources about Internet Banking}

The banks offer different types of services to the customer from time to time. Most of the time the modern services provided by the bank is not correctly communicated to the customer. So the researcher collected the information about the source through which the respondents got the information about the internet banking services. This piece of statistics has been presented in Table 1.2.

Table 1.2 Knowledge about Internet Banking Services

\begin{tabular}{|c|l|c|c|}
\hline S. No & \multicolumn{1}{|c|}{ Source } & Number of Respondents & Percentage \\
\hline 1 & Advertisement & 48 & 48 \\
\hline 2 & Friends and Relatives & 15 & 15 \\
\hline 3 & Bank Staff & 21 & 21 \\
\hline 4 & Bank Website & 16 & 16 \\
\hline & Total & 100 & 100 \\
\hline
\end{tabular}

Source: Primary Data

It is clear from the Table 1.2 that out of 100 respondents, 48 per cent have known from advertisement, 15 per cent of the informants got the information from the friends and relatives, 21 per cent of the customers are came to know about the Internet banking service through bank staff and the remaining 16 per cent of the respondents known from bank website.

\subsection{Reasons for Preferring Digital Banking Facilities}

Digital banking provides enormous facilities to the respondents. The investigator gathered the information about the factor which induce or urge the respondents to prefer online banking facilities. Table 1.3 shows the major reasons for utilizing the online banking by the respondents

Table 1.3 Reasons for Using Online Facilities

\begin{tabular}{|c|l|c|c|}
\hline S. No & \multicolumn{1}{|c|}{ Reasons } & $\begin{array}{c}\text { Number of } \\
\text { Respondents }\end{array}$ & Percentage \\
\hline 1 & Fund Transfer & 48 & 48 \\
\hline 2 & Electric Bill Presentation and Payment & 15 & 15 \\
\hline 3 & Checking Accounts Balance & 21 & 21 \\
\hline 4 & Online bill payment & 12 & 12 \\
\hline
\end{tabular}




\begin{tabular}{|c|l|c|c|}
\hline S. No & \multicolumn{1}{|c|}{ Reasons } & $\begin{array}{c}\text { Number of } \\
\text { Respondents }\end{array}$ & Percentage \\
\hline 5 & Business Purpose & 04 & 04 \\
\hline & Total & 100 & 100.00 \\
\hline
\end{tabular}

Source: Primary Data

It is clear from Table 1.3 that out of 100 respondents those who utilize the Digital Banking services, 48 per cent of the respondents utilize for Inter account fund transfer, 15 per cent of the customers for Electronic Bill presentation and payment use the Digital Banking banking, 21 per cent prefer for checking their account balance, 12 per cent utilize for online settlement of their bill, remaining 4 per cent prefer to Deposit and withdraw money at any time.

\subsection{Opinions about Service Charges of Digital Banking}

The bank collects the service charges from the accounts holders for providing the digital banking services. The researcher has gathered information about the opinion about service charges fixed by the bank and presented in the table 1.4.

Table 1.4 Opinions about the Service Charges

\begin{tabular}{|c|l|c|c|}
\hline Si.No & Level of Service Charges & Number of Respondents & Percentage \\
\hline 1 & Very high & 08 & 08 \\
\hline 2 & High & 29 & 29 \\
\hline 3 & Moderate & 39 & 39 \\
\hline 4 & Low & 24 & 24 \\
\hline & Total & 100 & 100 \\
\hline
\end{tabular}

Source: Primary Data

It is vivid from the Table 1.4 that out of 100 respondents, 8 per cent feel that the service charges are very high, 29 per cent pointed out that the charges are high, 39 per cent are feel moderate and the remaining 24 per cent feel that services charges are low.

\subsection{Problems Faced By the Respondents}

Even though the bank provides various services under digital banking scheme to their customers, sometime it creates some minor problems. The researcher has identified common problems faced by the respondents while using Digital banking. It is shown in the Table 1.5.

Table 1.5 Problems

\begin{tabular}{|c|l|c|c|}
\hline Si.No & \multicolumn{1}{|c|}{ Problems } & Number of Respondents & Percentage \\
\hline 1 & Network failure & 29 & 29 \\
\hline 2 & Errors in operation & 20 & 20 \\
\hline 3 & No security for internet dealing & 28 & 28 \\
\hline 4 & No Authenticated records & 17 & 17 \\
\hline 5 & Low speed and Delay & 06 & 06 \\
\hline & Total & 100 & 100 \\
\hline
\end{tabular}

Source: Primary Data

\subsection{Gap Analysis on the Respondents Perception}

The raw data obtained on the expectations of the respondents on all the fine dimensions of the quality, viz tangibles, reliability, assurance responders and empathy were used to calculate the

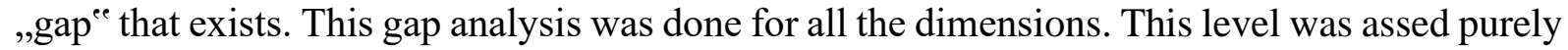
on the basis of their mean values development. 
Capering with a reference means value of, $5^{\text {ee }}$ which was considered to be the maximum taking in the account that any organization should like to achieve the gap, i.e. the difference between the respondents score and the reference mean value is the "service gap". Table 1.5 deals the service gap on all five dimensions of services.

Table 1.6 Gap Analysis of the Satisfaction Level of Respondent on Internet Banking Service

\begin{tabular}{|l|c|c|c|c|}
\hline \multicolumn{1}{|c|}{ Dimensions } & Expected Mean score & $\begin{array}{c}\text { Experienced Mean } \\
\text { Score }\end{array}$ & S.D & Service GAP \\
\hline IB Confident & 5 & 4.081081 & 0.872043 & 0.918919 \\
\hline IB Login & 5 & 3.932432 & 0.865330 & 1.067568 \\
\hline IB Information & 5 & 3.972973 & 0.827158 & 1.027027 \\
\hline IB Satisfied & 5 & 3.986486 & 0.851964 & 1.013514 \\
\hline IB Security & 5 & 3.648649 & 1.163750 & 1.351351 \\
\hline
\end{tabular}

Source: Primary Data

A service gap of greater than 2.5 was considered to be highly critical area for improvement of the performance dimensions. A service gap of less than 1.5 was treated as less significant and no need of treatment was required and a difference of 1.5 to 2.5 was considered as critical and it needed further improvement. It has been found that the following services need further improvement.

The above GAP analysis pointed out that, the customer are satisfied with the all the dimension of the Internet Banking Services.

\subsection{Satisfaction Level of the Customer}

The researcher has gathered information about the Internet Banking users ${ }^{\text {ee }}$ satisfaction level and presented in the Table 1.7.

Table 1.7 Satisfaction Level

\begin{tabular}{|c|l|c|c|}
\hline Si.No & Level of Satisfaction & Number of Respondents & Percentage \\
\hline 1 & Highly satisfied & 41 & 41 \\
\hline 2 & Satisfied & 30 & 30 \\
\hline 3 & Moderate & 18 & 18 \\
\hline 4 & Un satisfied & 07 & 07 \\
\hline 5 & Highly Unsatisfied & 04 & 04 \\
\hline & Total & 100 & 100.00 \\
\hline
\end{tabular}

Source: Primary Data

It is clear from the Table 1.7 that out of 100 respondents, 41 per cent of the respondents are highly satisfied with the Digital Banking services and only 4 per cent of the users are not satisfied with the Digital Banking services.

\subsection{Testing of Hypothesis}

There is no relationship between the socio economic factors of the respondents and their satisfaction. To test the hypothesis, the researcher has used Correlation analysis.

Table 1.7 (A) Relationship between Socio Economic and Digital Banking Service

\begin{tabular}{|l|c|c|c|c|c|c|c|}
\hline Variables & Gender & Age & Qualification & Employed & Sex & Income & Marital \\
\hline Digital Banking & -.151 & .065 & -.134 & -.041 & .172 & -.255 & .103 \\
\hline
\end{tabular}

The above Table 1.7 (A) shows that Digital Banking services don't have high positive correlation with the socio-economic factors. The correlation analysis shows the positive 
relationship with age (0.065), category (.172), marital status (.103) and negative relationship with gender (-.151), qualification (-.134), employment (-.041), income (-.255). So the hypotheses are rejected.

\section{CONCLUSIONS}

Banking system not only in coorgbut also in India emphasizes the need for automated banking. In coorgthe respondents and the satisfaction level. It is observed from the above Table 1.5 that out of 100 respondents 29 per cent of the respondents face network failure problems, 20.33 per cent of the respondents face error in operation, 27.67 per cent of the respondents feel that there is no security in e- dealings, 17.33 per cent think that there is no authentication records and the remaining 5.79 per cent of the respondents think that network delay problems.

Banking customers thinking to utilize the digital banking facilities with secured quality services rendered by their existing banks and also opening of new banks like SBI and other private commercial banks will create healthy competition among them leads to provide better new service opportunities. Based on the finding of the study, the following suggestions were made with a view to improve the customer service in the Digital banking System. Even though the Digital -banking provides innumerous facilities to the users ${ }^{\text {ee }}$ still the customer worry about the Security system offered by the banks. For this, banks must implements the following. Bank should install system supported by software and firewalls. It should be configured the highest security setting with the level protection according to the customers ${ }^{\text {ee }}$ needs. Bank should increase their ability to control and manage the various risks inherent to the e-transaction activities. Bank should implement more security to minimize the risk and increase customer authentication such as Personal Identification Number, Digital Signature, audit trail for transaction, etc. The banks have to focus on quality of services and also the banks should try to charge a reasonable service charge. The major problems faced by the employees of the bank are connectivity problems and power failure problem. To overcome these problems the branches should set up a preventive measure. Banks can have a tie-up with other banks so that the customers can transact between accounts of various types of banks. If any complaint is received by the banks it must be redressed immediately. Similarly the Bank staff must clear doubts of the customers in vernacular language.

\section{REFERENCES}

[1] Akinci, S., Aksoy, S. and Atilgan E., "Adoption of Internet banking among sophisticated consumer segments in an advanced developing country", International Journal of Bank Marketing, Vol. 22, No. 3, 2004, pp. 212-232

[2] Aldlaigan, A.H. and Buttle, F.A., "Consumer involvement in financial services: an empirical test of two measures", International Journal of Bank Marketing, Vol. 19 No.6, 2001, pp. 232-245

[3] Arunkumar S, Saranathan, "A Study on Attitude and Intention Towards Internet Banking With Reference to Malaysian Consumers in Klang Valley Region", The International Journal of Applied Management and Technology, Vol 6, Num 1, pp -115-146.

[4] Biju K, D. Devandhiran, "Customers" Satisfaction on Core Banking: A Study with special reference to a Nationalized Bank in Thirunelveli", International Journal of Research in Commerce \& Management, Volume 3, Issue no. 5, May, 2012, pp. 146-152.

[5] Deepak Jain “ Electronic Banking” IBA BULLETIN, Dec 2002

[6] Dr. Deepak Gupta; Dr. Vikrant Singh Tomar, “A Comparative Study of Customer Friendly Services of Selected Private \& Public Sector Bank In India : A Case Study Of ICICI Bank 
Vs SBI" Journal on Banking Fiancial Services and Insurance Research, Volume 1, Issue 9 (December, 2011), pp-28-39

[7] Khurana Sunayna, "Service Quality Gap And Customers' Satisfaction of Private Sector Banks: an Empirical Study", International Journal of Electronic Customer Relationship Management; Issue Volume 4, Number 1; 2010, pp 87 - 95.

[8] Mukherjee A and Nath P (2003), "A Model of trust in online relationship banking", International Journal of Bank Marketing, Vol. 21, No.1, pp.5-15.

[9] Nyangosiet al. "The evolution of e-banking: a study of Indian and Kenyan technology awareness", International Journal of Electronic Finance, Vol.3, No.2, 2009, pp.149-165.

[10] Venugopalan. M, "Implementation of core banking solutions to withstand competition" IBA BULLETIN, Feb 2005.

[11] Mishra A K (2005), "Internet Banking in India Part-I",

[12] http://www.banknetindia.com/ banking/ibkg.html, 15 Sept. 2010.

[13] http://knowledge.wharton.upenn.edu/article.cfm?articleid

[14] www.search.epnet.com

[15] www.financialexpress.com/fe/daily/19980 714/19555264.htm

[16] www.banking.com 